\title{
SEBUAH STUDI PADA WANITA BEKERJA: PENGARUH MOTIVATIONAL FACTORS, PURCHASE PREFERENCES, DAN TENDENCY TOWARDS HEALTH CONSCIOUSNESS TERHADAP PURCHASE INTENTION GREEN COSMETICS
}

\author{
Catresia Martha Bella \\ Universitas Negeri Surabaya \\ catresia.17080574025@mhs.unesa.ac.id \\ Yessy Artanti \\ Universitas Negeri Surabaya \\ yessyartanti@unesa.ac.ic
}

Abstract

\begin{abstract}
The study investigated the intention of working women to buy green cosmetic products. In addition, it also analyzes the relationship between motivational factors, purchase preferences, and tendency towards health consciousness on the purchase intention of green cosmetic products. A model was developed to understand the effect of independent variables on the dependent variable. Motivational factors, purchase preferences, and tendency towards health consciousness were considered as independent variables and purchase intention of green cosmetic products as the dependent variable. The survey was conducted using an online questionnaire and collected data from 119 working women. Multiple linear regression in SPSS software was used to analyze the collected data. The results show that motivational factors have no significant effect on the purchase intention of green cosmetics. Meanwhile, purchase preferences and tendency towards health consciousness significantly affect purchase intention of green cosmetics. This study focuses on a group of working women. Future research may involve demographic variables, spending on buying green products, and lifestyle variables. Further research can also use in-depth interviews and focus group discussions on finding out more details regarding the use of green products. The green product is also closely related to the high-involvement product. It becomes interesting to involve it in further research.
\end{abstract}

Keywords: green cosmetics; motivational factors; purchase preferences; tendency towards health consciousness, working women.

\section{PENDAHULUAN}

Perempuan cenderung suka berpenampilan menarik dibandingkan laki-laki (Melliana, 2006). Penampilan menarik dapat diwujudkan mulai dari merias diri sampai mengenakan pakaian yang dapat mendukung penampilan. Upaya lain yang dicoba yaitu dengan menjaga diri. Kegiatan menjaga diri bisa dicoba memakai produk tertentu untuk anggota badan mulai dari rambut sampai mata kaki (Khumaira \& Restu, 2018). Tidak sedikit perempuan menyadari makna kecantikan dengan mengalokasikan sebagian pengeluaran untuk membeli kosmetik maupun pergi ke salon kecantikan (Rukmawati \& Dzulkarnain, 2015).

Peluang bisnis kosmetik di Indonesia terbilang potensial dikarenakan demografi populasi perempuan yang mencapai 130 juta jiwa serta 68\% nya merupakan perempuan usia produktif (Katadata, 2019). Pertumbuhan industri kosmetik di Indonesia ini tercatat mengalami kenaikan sebesar $20 \%$ pada tahun 2017 (Kemenperin, 2018). Seiring pesatnya pertumbuhan bisnis kosmetik, industri kosmetik mulai memperluas segmen pasarnya dengan melakukan berbagai inovasi (Yohana, 2020).

Industri kosmetik mengandung subkategori seperti produk perawatan kulit, produk perawatan rambut, kosmetik warna, wewangian, dan produk perawatan pribadi (Khan \& Salim, 2020). Industri kosmetik modern menggunakan berbagai macam bahan kimia seperti paraben, petrokimia, sodium lauryl sulphate, pewarna, dan pengawet buatan. Tidak ada keraguan bahwa paparan jangka panjang terhadap bahan kimia tersebut dapat menyebabkan banyak masalah kesehatan, seperti kanker, dermatitis, dan alergi (Liobikienė \& Bernatonienè, 2017). Kosmetik berbahan dasar kimia berakibat negatif dan berpotensi membahayakan pengguna kosmetik kimia karena memiliki banyak kekurangan, di 
Catresia Martha Bella \& Yessy Artanti. Sebuah Studi pada Wanita Bekerja: Pengaruh Motivational Factors, Purchase Preferences, dan Tendency towards Health Consciousness terhadap Purchase Intention Green Cosmetics.

antaranya pergantian pada warna kulit, dapat menyebabkan bercak-bercak gelap pada kulit, alergi, iritasi kulit, kerusakan permanen pada lapisan syaraf, semacam tremor, insomnia, kepikunan, kendala penglihatan, gerakan tangan abnormal, kendala emosi, otak, ginjal, dan kendala pertumbuhan janin (Trisnawati, Yulianti, \& Ebtavanny, 2017).

Konsumen yang menghindari paparan yang tidak diinginkan terhadap bahan pengawet, bahan sintetis, hormon, produk bioteknologi, dan residu pestisida lebih cenderung menggunakan green cosmetics (kosmetik organik/ramah lingkungan) (Liobikiené \& Bernatoniené, 2017). Mansur (2009) menyatakan bahwa green cosmetics tidak berbahaya bagi kulit. Hal ini yang kemudian memotivasi konsumen untuk menggunakan kosmetik berbahan dasar alami dibanding dengan kosmetik berbahan dasar kimia yang beresiko membahayakan kulit penggunanya (Martha \& Febriyantoro, 2019). Kosmetik dinyatakan green cosmetics apabila terbuat dari bahan alami serta produksinya dilakukan tanpa membahayakan lingkungan (Sindo, 2012).

Di Indonesia, green cosmetics belum banyak diketahui oleh konsumen. Walaupun demikian, terdapat banyak green cosmetics yang diterima dengan baik oleh pasar Indonesia (Weddy \& Febrya, 2016). Di antaranya, The Body Shop, Lush cosmetic, Runa Beauty, Aromatica, Elate Cosmetic, ZAO Organic Makeup, Loli Beauty, Leaf Juice Skincare, Oriflame, Innisfree, Clarins, Afterglow, Skin Dewi, L’Occitane, Khiel's, dan Sensatia Botanicals (Arum, 2019; Cleanomic, 2020; Grace, 2020).

Pra-penelitian dilakukan pada 30 responden wanita bekerja yang ditanyai tentang merek green cosmetics yang mereka ketahui. Hasil pra-penelitian menunjukkan bahwa merek green cosmetics yang paling banyak diketahui oleh responden yang pertama adalah Oriflame, terbanyak kedua adalah Nature Republic, dan diikuti ketiga merek selanjutnya yaitu Innisfree, The Body Shop, dan Sensatia Botanicals. Khan \& Salim dalam penelitiannya menyatakan bahwa perempuan bekerja lebih sadar akan green cosmetics dibanding pelajar ataupun perempuan yang telah berumah tangga (Khan \& Salim, 2020).

Perilaku konsumen wanita terhadap green cosmetics telah menjadi perhatian yang menarik bagi para peneliti. Beberapa penelitian menyatakan bahwa kesadaran akan kesehatan berpengaruh positif terhadap niat pembelian green cosmetics (Carey \& Cervellon, 2011; Ghazali et al., 2017; Khan \& Salim, 2020). Khan \& Salim (2020) dalam penelitiannya menyatakan bahwa faktor lain yang berpengaruh positif terhadap niat pembelian green cosmetics yakni motivational factor dan purchase preferences (Khan \& Salim, 2020).

Niat pembelian merupakan bagian dari evalusi alternatif pra-pembelian pada model proses keputusan pembelian konsumen (Blackwell, Miniard, \& Engel, 2012). Penelitian menunjukkan bahwa konsumen wanita memiliki niat pembelian terhadap green cosmetics karena sadar akan kesehatan (Khan \& Salim, 2020). Menurut Kotler \& Armstrong (2011), keputusan untuk membeli diambil oleh satu orang di mana orang lain dalam keluarga atau teman memengaruhi pembelian dengan memotivasi pembeli individu.

Motivational factors terpenting untuk membeli produk mungkin melibatkan locus of control pelanggan sebagai pemrakarsa, pengguna, atau pembeli produk. (Khan \& Salim, 2020). Motivasi seseorang untuk tampil cantik sering kali mengalahkan kewajiban menjaga kesehatan kulit dan tubuh. Motivasi yang seharusnya mengarah kepada hasil yang positif berakhir dengan hasil yang negatif dikarenakan banyak dari mereka yang menggunakan kosmetik berbahan kimia (Widiyani, 2018). Sebuah study menyatakan bahwa kepercayaan terhadap produk ramah lingkungan sangat menentukan perilaku pembelian ramah lingkungan (Liobikiene, Mandravickaite, \& Bernatoniene, 2016). Selain kepercayaan, Boztepe (2012) dan Braimah (2015) menegaskan bahwa harga jelas dipilih sebagai determinan yang paling relevan dalam memengaruhi keputusan pembelian responden mereka. Namun, Ritter et al. (2015) menunjukkan bahwa hubungan antara harga dan kualitas tidak memainkan peran sentral dalam keputusan untuk mengkonsumsi produk ramah lingkungan (Liobikienè \& Bernatonienè, 2017). 
Purchase preferences diidentifikasi sebagai salah satu faktor dalam memprediksi sikap terhadap green cosmetics (Khan \& Salim, 2020). Hal ini disebabkan oleh perbedaan alasan konsumen terkait preferensi mereka. Konsumen memiliki tingkat kesensitifan yang berbeda terhadap jenis, harga produk, dan status sosial ekonomi yang akan memengaruhi pembelian (Sundarambal \& Edhayavarman, 2017). Beberapa penelitian menyatakan bahwa purchase preferences berpengaruh terhadap niat pembelian green cosmetics (Khan \& Salim, 2020; Puh, 2016).

Tendency towards health consciousness secara empiris diidentifikasi sebagai determinan dalam memprediksi sikap terhadap green cosmetics (Khan \& Salim, 2020). Konsumen yang sadar kesehatan sering kali mencakup tingkat kesadaran dan perhatian yang tinggi tentang keadaan kesejahteraan mereka daripada konsumen yang kurang sadar kesehatan. Selain itu, konsumen yang sadar kesehatan cenderung memiliki pengetahuan yang luas tentang peran gizi dan kebugaran fisik dalam kesehatan dan kualitas hidup mereka (Bhatnagar \& Ghose, 2004; Gould, 1988; Lee, 2016). Puh (2016) tidak dapat membuktikan penelitian terkait kesadaran kesehatan konsumen terhadap niat pembelian (Puh, 2016). Akan tetapi, penelitian lain membuktikan bahwa kesadaran kesehatan konsumen berpengaruh terhadap purchase intention (Ghazali et al., 2017; Khan \& Salim, 2020; Sadiq, Adil, \& Paul, 2020).

Berdasarkan uraian di atas, tujuan penelitian ini yaitu menguji dan menganalisis pengaruh motivational factors, purchase preferences, dan tendency towards health terhadap purchase intention green cosmetics (studi pada wanita bekerja).

\section{KAJIAN PUSTAKA DAN PENGEMBANGAN HIPOTESIS}

\section{Purchase Intention}

Menurut Kotler \& Keller (2016), purchase intention adalah sebuah perilaku konsumen yang di dalamnya konsumen mempunyai keinginan untuk membeli atau memilih suatu produk berdasarkan pengalaman dalam memilih, menggunakan, dan mengkonsumsi atau bahkan menginginkan suatu produk. Davari et al. (2017) berpendapat bahwa indikator purchase intention yaitu willingness to try. Shukla, S. (2019) dan Kim \& Chung (2011) menyatakan bahwa indicator purchase intention yaitu willingness to buy. Sedangkan menurut Hsu et al. (2017), indikator purchase intention yaitu willingness to recommend.

\section{Motivational Factors}

Motivational factors merupakan kekuatan pendorong yang memaksa seseorang untuk melakukan tindakan. Motivasi sebagai faktor pendorong muncul karena adanya kebutuhan. Sebagian besar kebutuhan spesifik individu memiliki gairah yang terhitung oleh waktu. Gairah atau arousal ini disebabkan oleh rangsangan internal yang ditemukan psikologi manusia, proses emosional atau kognitif, serta rangsangan di lingkungan luar (Newman \& Japarianto, 2014; Schiffman \& Kanuk, 2007). Motivasi memainkan peran penting dalam proses pembelian konsumen. Motif berawal dari kebutuhan individu di mana terdapat tekanan yang kuat untuk mencari kepuasan dan kesenangan (Kotler \& Amstrong, 2011). Motivational factors merupakan faktor pendorong bagi konsumen memenuhi kebutuhan mereka dengan melakukan pembelian (Chin et al., 2018). Indikator motivational factors menurut Khan \& Salim (2020:3) yaitu: belief, price, scientific evidence, celebrity endorser, dan medicinal value.

\section{Purchase Preferences}

Preferensi didefinisikan sebagai selera individu terhadap suatu barang yang diukur dengan kepuasan (Wetzstein, 2020). Sekumpulan asumsi yang berfokus pada pilihan konsumen yang menghasilkan alternatif yang berbeda seperti kebahagiaan, kepuasan, atau utilitas (Lombardo, 2020). Preferensi memengaruhi kemauan untuk membeli barang (Banks, 2014). Preferensi konsumen melibatkan peringkat barang dan jasa sesuai dengan seberapa banyak keuntungan yang mereka dapatkan (Cox \& Grether, 1993). Indikator purchase preferences menurut Khan \& Salim (2020:3) yaitu: frequency of buying, dan proximity to buy. Sedangkan Sharmila Pudaruth, Thanika Devi Juwaheer, Yogini Devi Seewoo (2015:187) berpendapat bahwa purchase preferences dapat diukur melalui hal-hal berikut. (1) 
Catresia Martha Bella \& Yessy Artanti. Sebuah Studi pada Wanita Bekerja: Pengaruh Motivational Factors, Purchase Preferences, dan Tendency towards Health Consciousness terhadap Purchase Intention Green Cosmetics.

Women lifestyles, self-image, health, dan economic considerations. (2) Ethical consumerism. (3) Belief of ethical claims in green messages.

\section{Tendency towards Health Consciousness}

Aspek kesehatan dari konsumsi organik sering dikaitkan dengan tidak adanya bahan kimia, seperti pestisida dan pupuk berbasis kimia, yang digunakan dalam pertanian (Ghazali et al., 2017; Lee, 2010). Perhatian kesehatan pada individu menunjukkan konsep pro-diri (kepedulian terhadap diri sendiri atau keluarga), sehingga dapat dipahami bersifat egois (Magnusson et al., 2003; Yadav, 2016). Masalah kesehatan disebut sebagai sejauh mana konsumen berada sadar akan masalah kesehatan dan bersedia menyelesaikan masalah yang berkaitan dengan kesehatan (Yadav, 2016). Indikator tendency towards health consciousness menurut Khan \& Salim (2020) yaitu: health consciousness, dan sense of environment-friendly.

\section{Hubungan antar Variabel}

Motivasi sebagai faktor pendorong disebabkan oleh kebutuhan rasional dan kebutuhan emosional (Wu, Chen, \& Chung, 2010). Dua jenis motivasi ini dapat memengaruhi keputusan pembelian konsumen, motivasi rasional (berdasarkan objektivitas dalam menilai produk) dan motivasi emosional (berdasarkan subjektivitas dalam menilai produk) (Setiadi, 2013). Motivasi yaitu efek internal yang menginisiasi aktivitas pribadi, mempertahankan aktivitas pribadi, dan dorongan yang memaksa individu ke berbagai perilaku (Carlson \& O'Cass, 2010). Oleh karena itu, dalam membeli produk tertentu, motivasi rasional dan motivasi emosional dapat memengaruhi keputusan pembelian konsumen (Setiadi, 2013).

H1: Terdapat pengaruh positif antara motivational factors terhadap purchase intention.

Purchase preferences dinyatakan sebagai salah satu faktor penting yang memengaruhi niat beli konsumen. Persepsi konsumen terkait produk didasarkan pada lebih dari satu atribut, jadi sangat penting untuk mengidentifikasi atribut mana memengaruhi niat konsumen untuk membeli (Anojan \& Subaskaran, 2015). Penetapan harga produk adalah keputusan penting untuk bisnis apa pun, terutama ketika memperkenalkan produk baru ke dalam pasar. Harga tidak hanya berfungsi sebagai indikator pengorbanan moneter tetapi juga merupakan indikator kualitas produk. Harga dapat digunakan oleh pelanggan untuk mengevaluasi kualitas produk, di mana produk dengan harga mahal dianggap memiliki kualitas dan nilai yang lebih tinggi dibandingkan barang dengan harga murah (Suri \& Monroe, 2003; Zeithaml, 1988). Penawaran dan iklan yang diberikan oleh produsen merupakan aspek penting lainnya yang memengaruhi purchase preferences (Khan \& Salim, 2020). Purchase preferences memiliki hubungan positif terhadap purchase intention (Anojan \& Subaskaran, 2015; Banks, 2014; Khan \& Salim, 2020).

$\mathrm{H} 2$ : Terdapat pengaruh positif antara purchase preferences terhadap purchase intention.

Sebuah studi menyatakan kesadaran kesehatan membimbing orang untuk terlibat dalam perilaku sehat (Becker et al., 1977). Konsumen yang sadar kesehatan peduli tentang keadaan kesejahteraan yang diinginkan dan melakukan upaya untuk mempertahankan hidup sehat (Newsom et al., 2005). Dalam konteks pembelian produk perawatan kulit/rambut, konsumen dengan kesadaran kesehatan yang tinggi dapat mempertimbangkan apakah suatu produk aman bagi kulit dan tubuh. Oleh karena itu, konsumen lebih memperhatikan jenis bahan yang digunakan untuk membuat produk perawatan kulit/rambut (Johri \& Sahasakmontri, 1999). Dengan demikian, konsumen yang memiliki kepedulian tinggi terhadap kesehatan lebih cenderung untuk mengkonsumsi produk ramah lingkungan karena mereka menganggap kesehatan sebagai parameter saat memilih produk (Molinillo et al., 2020; Sadiq et al., 2020; Tandon et al., 2020). Rancangan penelitian ini digambarkan pada gambar 1.

H3: Terdapat pengaruh positif antara tendency towards health consciousness terhadap purchase Intention. 


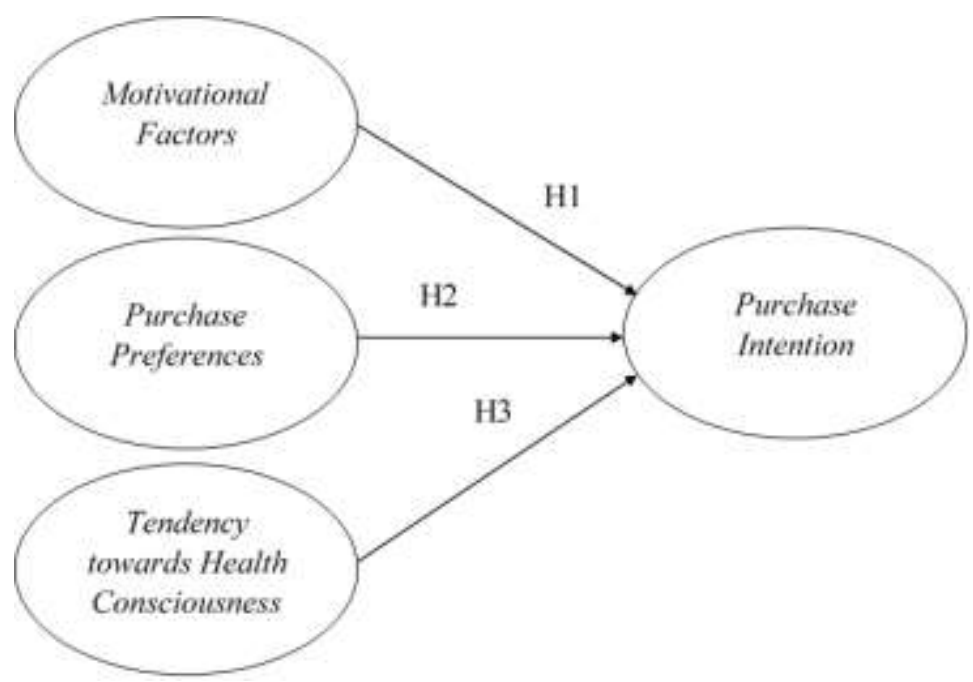

Gambar 1. RANCANGAN PENELITIAN

\section{METODE PENELITIAN}

Jenis penelitian ini yaitu penelitian konklusif. Dalam studi ini, wanita bekerja sebagai populasi dengan karakteristik minimal pendidikan S1 dan usia adalah 21-64 tahun. Metode pengambilan sampel yang digunakan dalam penelitian ini adalah nonprobability sampling dengan teknik pengambilan sampel adalah judgemental sampling. Sampel pada penelitian ini berjumlah 119 responden (Sugiyono, 2017). Penyebaran angket menggunakan Google form dan dilakukan secara online. Angket disebarkan melalui media sosial Whatsapp, Instagram, dan Facebook. Pernyataan-pernyataan dalam angket telah divalidasi oleh ahli di bidang pemasaran dan diuji validitas dan reliabilitasnya menggunakan perhitungan nilai $r$ dan nilai Cronbach Alpha sehingga dihasilkan 35 butir pernyataan. Bagian pertama angket merupakan pertanyaan yang digunakan untuk memfilter responden agar sesuai dengan karakteristik responden yang diharapkan. Bagian kedua merupakan pernyataan-pernyataan untuk mengukur variabel penelitian dengan menggunakan skala Likert (1-sangat tidak setuju, 2-tidak setuju, 3-ragu-ragu, 4-setuju , 5-sangat setuju). Butir pernyataan angket dapat dilihat di tabel 1. Bagian ketiga merupakan pertanyaan demografis. Bagian keempat yaitu pertanyaan terbuka terkait green product yang diolah secara deskriptis dan akan dijelaskan di bagian hasil. Regresi linier berganda digunakan untuk menganalisis data. Software yang digunakan yaitu IBM SPSS Statistics 26.0.

\section{HASIL DAN PEMBAHASAN}

\section{Profil Responden}

Karakteristik responden dalam penelitian ini yaitu wanita bekerja usia 21-64 tahun dan minimal pendidikan S1. Mayoritas responden dalam penelitian ini yaitu seorang wirausaha rentang usia 21-30 tahun. Data tersebut menandakan bahwa responden didominasi oleh wanita bekerja dengan klasifikasi usia dewasa muda (Papalia et al., 2007). Data selengkapnya dapat dilihat dalam tabel 2.

\section{Uji Validitas dan Reliabilitas}

Uji validitas telah dilakukan pada 30 sampel dan didapatkan hasil yang menunjukkan bahwa seluruh butir pernyataan dapat dijadikan sebagai alat ukur sebab seluruh butir pernyataan dinyatakan valid. Kevalidan butir pernyataan dapat dilihat dari nilai $r$ hitung $>r$ tabel sebesar 0,361 . Selanjutnya pada uji reliabilitas, nilai Cronbach Alpha pada variabel motivational factors sebesar 0,929, purchase preferences sebanyak 0,948, dan tendency towards health consciousness sebesar 0,946. Nilai Cronbach Alpha tersebut menunjukkan bahwa seluruh butir pernyataan yang digunakan pada penelitian ini reliabel. Butir pernyataan dinyatakan reliabel apabila nilai Cronbach Alpha > 0,60 (Sugiyono, 2017). 
Catresia Martha Bella \& Yessy Artanti. Sebuah Studi pada Wanita Bekerja: Pengaruh Motivational Factors, Purchase Preferences, dan Tendency towards Health Consciousness terhadap Purchase Intention Green Cosmetics.

\section{Tabel 1. BUTIR PERNYATAAN ANGKET}

\begin{tabular}{|c|c|c|}
\hline Variabel & Butir Pernyataan Angket & Sumber \\
\hline $\begin{array}{l}\text { Motivational } \\
\text { factors }\end{array}$ & $\begin{array}{l}\text { Saya percaya bahwa produk kosmetik ramah lingkungan itu lebih } \\
\text { sehat. } \\
\text { Saya percaya bahwa produk kosmetik ramah lingkungan lebih } \\
\text { aman dibanding yang tidak ramah lingkungan. } \\
\text { Saya percaya bahwa produk kosmetik ramah lingkungan tidak } \\
\text { mengandung zat yang berbahaya. } \\
\text { Saya bersedia membayar produk kosmetik ramah lingkungan } \\
\text { dengan harga mahal. } \\
\text { Saya bersedia menambah pengeluaran per bulan untuk membeli } \\
\text { produk kosmetik ramah lingkungan. } \\
\text { Harga bukan menjadi hal yang terpenting ketika saya membeli } \\
\text { produk kosmetik ramah lingkungan. } \\
\text { Biaya yang saya bayarkan untuk membeli produk kosmetik } \\
\text { ramah lingkungan sebanding dengan manfaat yang saya } \\
\text { dapatkan. } \\
\text { Komposisi produk kosmetik ramah lingkungan meningkatkan } \\
\text { kepercayaan saya terhadap kosmetik ramah lingkungan. } \\
\text { Manfaat produk kosmetik ramah lingkungan meningkatkan } \\
\text { kepercayaan saya terhadap kosmetik ramah lingkungan. } \\
\text { Saya lebih percaya pada produk kosmetik ramah lingkungan } \\
\text { yang melibatkan artis dalam iklannya. } \\
\text { Saya lebih mencari produk kosmetik yang mengandung bahan } \\
\text { alam dibanding bahan kimia. }\end{array}$ & $\begin{array}{l}\text { Ghazali, E., Soon, P. C., } \\
\text { Mutum, D. S., \& Nguyen, } \\
\text { B. (2017), Hsu, C. L., } \\
\text { Chang, C. Y., \& } \\
\text { Yansritakul, C. (2017), } \\
\text { Khan, S., \& Salim, A. } \\
\text { (2020), Liobikiene, G., } \\
\text { Mandravickaite, J., \& } \\
\text { Bernatoniene, J. (2016), } \\
\text { dan Sharmila Pudaruth, } \\
\text { Thanika Devi Juwaheer, } \\
\text { Yogini Devi Seewoo, } \\
\text { (2015). }\end{array}$ \\
\hline $\begin{array}{l}\text { Purchase } \\
\text { preferences }\end{array}$ & $\begin{array}{l}\text { Saya sering membeli produk ramah lingkungan. } \\
\text { Saya lebih suka membeli produk kosmetik ramah lingkungan } \\
\text { yang dijual di dekat tempat tinggal saya. } \\
\text { Saya bisa mendapatkan produk kosmetik ramah lingkungan } \\
\text { dengan mudah. } \\
\text { Saya dapat menemukan produk kosmetik ramah lingkungan yang } \\
\text { dijual secara online. } \\
\text { Produk kosmetik ramah lingkungan sesuai dengan gaya hidup } \\
\text { saya. } \\
\text { Produk kosmetik ramah lingkungan sesuai dengan citra diri saya. } \\
\text { Saya percaya bahwa produk kosmetik ramah lingkungan lebih } \\
\text { bermanfaat dibanding kosmetik lainnya. } \\
\text { Saya percaya bahwa memilih produk kosmetik ramah lingkungan } \\
\text { adalah hal yang baik untuk lingkungan. } \\
\text { Saya memilih kosmetik yang tidak menggunakan hewan untuk } \\
\text { percobaan. } \\
\text { Pilihan saya terhadap produk kosmetik ramah lingkungan } \\
\text { dipengaruhi oleh iklan kosmetik ramah lingkungan tersebut. } \\
\text { Informasi dalam kemasan produk kosmetik ramah lingkungan } \\
\text { disampaikan dengan jelas. } \\
\text { Iklan produk kosmetik ramah lingkungan menyampaikan } \\
\text { informasi dengan jujur. } \\
\text { Saya merasa puas dengan produk kosmetik ramah lingkungan. }\end{array}$ & $\begin{array}{l}\text { Khan, S., \& Salim, A. } \\
\text { (2020), Liobikiene, G., } \\
\text { Mandravickaite, J., \& } \\
\text { Bernatoniene, J. (2016), } \\
\text { dan Sharmila Pudaruth, } \\
\text { Thanika Devi Juwaheer, } \\
\text { Yogini Devi Seewoo, } \\
\text { (2015). }\end{array}$ \\
\hline $\begin{array}{l}\text { Tendency } \\
\text { towards health } \\
\text { consciousness }\end{array}$ & $\begin{array}{l}\text { Saya memilih produk yang ramah lingkungan untuk menjaga } \\
\text { kesehatan saya. } \\
\text { Saya percaya bahwa produk kosmetik ramah lingkungan akan } \\
\text { membuat saya hidup lebih sehat. } \\
\text { Saya ingin menjadi orang yang peduli lingkungan dalam semua } \\
\text { aspek kehidupan saya. } \\
\text { Saya sangat peduli terhadap lingkungan. }\end{array}$ & $\begin{array}{l}\text { Ghazali, E., Soon, P. C., } \\
\text { Mutum, D. S., \& Nguyen, } \\
\text { B. (2017), Khan, S., \& } \\
\text { Salim, A. (2020), Sadiq, } \\
\text { M., Adil, M., \& Paul, J. } \\
\text { (2020), dan Shukla, S. } \\
\text { (2019). }\end{array}$ \\
\hline
\end{tabular}




\begin{tabular}{lll}
\hline Variabel & Butir Pernyataan Angket & Sumber \\
\hline Purchase & Saya akan mencoba produk kosmetik ramah lingkungan. & Arezoo Davari, Pramod \\
& Saya akan membeli produk kosmetik ramah lingkungan. & Iyer \& David Strutton \\
& Saya akan membeli produk kosmetik ramah lingkungan karena & (2017), Hsu, C. L., Chang, \\
& tidak menimbulkan polusi. & C. Y., \& Yansritakul, C. \\
& Saya akan beralih ke produk kosmetik ramah lingkungan karena & (2017), dan Shukla, S. \\
& tidak merusak lingkungan. & $(2019)$. \\
& Saya akan membeli produk kosmetik ramah lingkungan segera & \\
& setelah kosmetik yang sedang saya gunakan habis. & \\
& Saya akan membeli produk kosmetik ramah lingkungan dalam & \\
& waktu dekat untuk berkontribusi pada lingkungan. & \\
& Saya akan merekomendasikan produk kosmetik ramah & \\
& lingkungan ke orang-orang yang saya kenal. &
\end{tabular}

Sumber: Data diolah.

Tabel 2. KARAKTERISTIK RESPONDEN

\begin{tabular}{|c|c|c|c|}
\hline & Karakeristik & Jumlah & Persentase \% \\
\hline Jenis kelamin & Perempuan & 119 & $100 \%$ \\
\hline \multirow[t]{5}{*}{ Usia } & $<20$ tahun & - & $0 \%$ \\
\hline & $21-30$ tahun & 104 & $87 \%$ \\
\hline & 31-40 tahun & 7 & $6 \%$ \\
\hline & 41-50 tahun & 7 & $6 \%$ \\
\hline & $>51$ tahun & 1 & $1 \%$ \\
\hline Pendidikan terakhir & S1 & 119 & $100 \%$ \\
\hline \multirow[t]{8}{*}{ Pekerjaan } & Tenaga kependidikan & 25 & $21 \%$ \\
\hline & Tenaga medis & 4 & $3,5 \%$ \\
\hline & Karyawan swasta & 22 & $18 \%$ \\
\hline & TNI Polri & 1 & $1 \%$ \\
\hline & Wirausaha & 38 & $32 \%$ \\
\hline & Pegawai negeri & 4 & $3,5 \%$ \\
\hline & BUMN & 1 & $1 \%$ \\
\hline & Lainnya & 24 & $20 \%$ \\
\hline \multirow[t]{5}{*}{ Pengeluaran per bulan } & $<$ Rp. 3.000.000 & 77 & $65 \%$ \\
\hline & $\begin{array}{l}\text { Rp. 3.000.001 - Rp. } \\
4.000 .000\end{array}$ & 10 & $8 \%$ \\
\hline & $\begin{array}{l}\text { Rp. 4.000.001 - Rp. } \\
5.000 .000\end{array}$ & 4 & $3 \%$ \\
\hline & $>$ Rp. 5.000 .001 & 8 & $7 \%$ \\
\hline & Lainnya & 20 & $17 \%$ \\
\hline
\end{tabular}

Sumber: Data diolah.

\section{Uji Asumsi Klasik}

Pengujian asumsi klasik terdiri atas uji normalitas, uji multikolinieritas, dan uji heteroskedastisitas. Uji normalitas untuk mengetahui apakah variabel dependent, independent atau keduanya berdistribusi normal, mendekati normal atau tidak. Hasil uji normalitas ini dikatakan berdistribusi normal sebab One-Sampel Kolmogrov-Smirnov Test menunjukkhan hasil Asymp. Sig. (2-tailed) sebesar 0,200 lebih besar dari 0,05 . Selanjutnya yaitu uji multikolinieritas untuk mengetahui apakah pada model regresi yang diajukan telah ditemukan korelasi kuat antar variabel independent. Hasil uji menunjukkan bahwa tidak terjadi kolerasi diantara variabel independent. Hal tersebut dapat dilihat dari besarnya nilai VIF < 10. Uji heteroskedastisitas untuk mengetahui apakah dalam model regresi, terjadi ketidaksamaan varians dari residual suatu pengamatan ke pengamatan lain. Uji dapat dilakukan dengan melihat pola gambar scatterplots, pada penelitian ini gambar scatterplots titik-titik menyebar disekitar angka 0 , tidak berpola, tidak membentuk pola bergelombang melebar kemudian menyempit dan melebar kembali, dan tidak mengumpul di satu area. Hal tersebut menandakan bahwa tidak terjadi gejala heteroskedastisitas. Model regresi linier berganda pada penelitian ini dikatakan baik karena 
Catresia Martha Bella \& Yessy Artanti. Sebuah Studi pada Wanita Bekerja: Pengaruh Motivational Factors, Purchase Preferences, dan Tendency towards Health Consciousness terhadap Purchase Intention Green Cosmetics.

model tersebut memenuhi asumsi normalitas data dan terbatas dari asumsi-asumsi klasik statistik baik multikolineritas dan heteroskesdatisitas.

\section{Regresi Linier Berganda}

Tabel 3.

HASIL UJI REGRESI

\begin{tabular}{llc}
\hline Model & t & Sig. \\
\hline (Constant) & 0,662 & 0,509 \\
Motivational factors & 1,467 & 0,145 \\
Purchase preferences & 4,163 & 0,000 \\
Tendency towards health consciousness & 4,478 & 0,000 \\
\hline
\end{tabular}

Sumber: Data diolah.

Hasil uji f menunjukkan bahwa nilai signifikansi sebesar $0,000<0,05$. Angka tersebut mengindikasikan bahwa motivational factors, purchase preferences, dan tendency towards health consciousness secara simultan berpengaruh signifikan terhadap purchase intention green cosmetics pada wanita bekerja. Besarnya pengaruh ini dapat dilihat dari nilai $\mathrm{R}$ square sebesar 0,591 artinya variabel motivational factors, purchase preferences, dan tendency towards health consciousness memengaruhi sebesar 59,1\% sedangkan 40,9\% dipengaruhi oleh variabel lain yang tidak diteliti dalam penelitian ini. Selain uji f, uji t dilakukan dan didapatkan hasil nilai signifikansi motivational factors sebesar 0,145 >0,05, nilai signifikansi purchase preferences $0,000<0,05$, dan nilai signifikansi tendency towards health consciousness $0,000<0,05$. Artinya, H1 tidak terbukti sedangkan $\mathrm{H} 2$ dan $\mathrm{H} 3$ terbukti.

\section{Hasil Pertanyaan Terbuka}

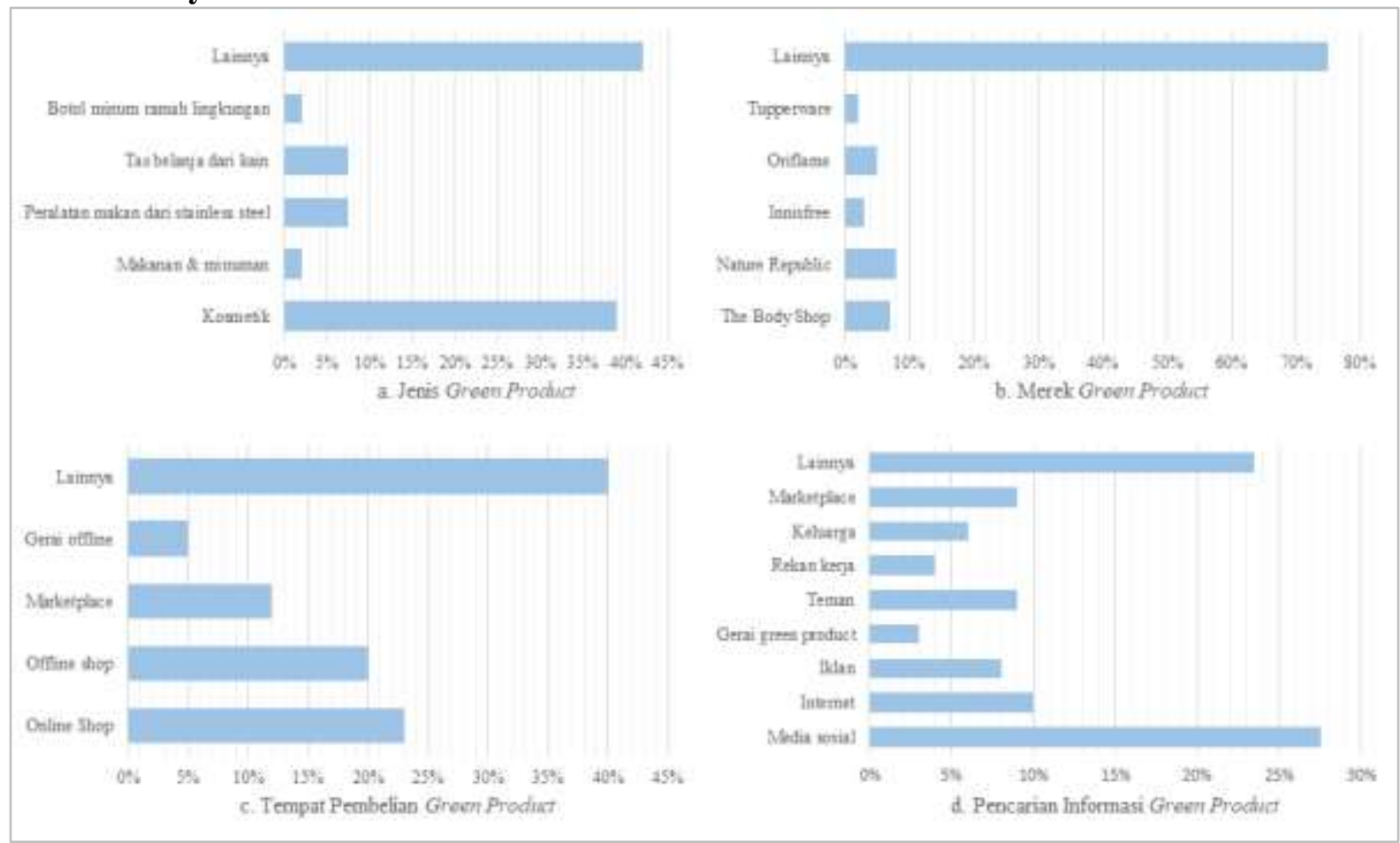

Sumber: Data diolah.

Gambar 2. PERSENTASE HASIL PERTANYAAN TERBUKA

Gambar 2 menunjukkan 39\% wanita bekerja menggunakan jenis green product berupa kosmetik. Selain itu, terdapat $2 \%$ wanita bekerja mengkonsumsi makanan dan minuman sehat, 7,5\% menggunakan peralatan makan dari stainless steel, 7,5\% menggunakan tas belanja dari kain, $2 \%$ 
menggunakan botol minuman ramah lingkungan, dan $42 \%$ menggunakan green product lainnya. Nature Republic menjadi merek yang paling banyak disebutkan oleh wanita bekerja. Persentase Nature Republic sebesar 8\%, The Body Shop sebesar 7\%, Oriflame sebesar 5\%, Innisfree sebesar 3\%, $2 \%$ untuk merek Tupperware dan $72 \%$ wanita bekerja tidak menyebutkan merek apa yang mereka gunakan. Pembelian secara online banyak diminati wanita bekerja. Data menunjukkan $23 \%$ wanita bekerja membeli green product secara online, $20 \%$ melakukan pembelian di offline shop seperti minimarket dan toko green product terdekat, $12 \%$ melakukan pembelian di marketplace, 5\% wanita bekerja membeli langsung di gerai offline green product tersebut, dan $40 \%$ wanita bekerja tidak menyebutkan secara spesifik tempat mereka melakukan pembelian. Sebelum melakukan pembelian green product, wanita bekerja melakukan pencarian informasi terkait green product yang ingin dibeli. Media sosial menjadi aplikasi yang paling banyak dipilih wanita bekerja dengan persentase sebesar $27,5 \%$. Selanjutnya, $10 \%$ wanita bekerja memilih melakukan pencarian informasi melalui internet, $8 \%$ dari iklan, 3\% dari gerai green product, $4 \%$ dari rekan kerja, $9 \%$ dari teman, $6 \%$ dari keluarga, $9 \%$ dari marketplace, dan $23,5 \%$ tidak memberikan responnya.

\section{Pengaruh Motivational Factors terhadap Purchase Intention}

H1 tidak terbukti yang artinya variabel motivational factors tidak memiliki pengaruh signifikan terhadap purchase intention. Hasil ini tidak sama dengan hasil penelitian yang dilakukan (Khan \& Salim, 2020) yang menyatakan bahwa motivational factors memiliki pengaruh signifikan positif terhadap purchase intention green cosmetics.

Wanita bekerja dalam usia produktif cenderung memiliki keberanian dalam mengambil keputusan, baik yang beresiko maupun tidak. Mengambil risiko tidak selalu berarti melakukan hal-hal yang sembrono, tetapi itu juga berarti membuat keputusan yang diperhitungkan dan mencoba hal-hal yang mungkin dianggap "berisiko" (Jones, 2021). Responden penelitian ini berani mengambil resiko dengan menggunakan kosmetik konvensional. Hasil penelitian menunjukkan bahwa meskipun motivational factors tidak berpengaruh terhadap purchase intention green cosmetics, banyak responden telah menggunakan green product. Hal ini ditengarai disebabkan oleh harga green cosmetics yang cenderung premium. Wanita bekerja lebih memilih mengeluarkan biaya untuk membeli green product yang tahan lama seperti peralatan makan yang terbuat dari selain plastik, dan totebag ataupun tas belanja yang terbuat dari kain. Meskipun pada dasarnya mereka mampu melakukan pembelian green cosmetics yang lebih aman untuk kesehatan tubuh dan wajah, tetap saja kosmetik konvensional masih mendominasi pilihan wanita bekerja ketika mereka melakukan pembelian. Pemasar perlu menggencarkan sosialisasi terkait bahaya penggunaan kosmetik kimia karena dimungkinkan masih banyak wanita bekerja yang tidak mengetahui seluk beluk tentang perkosmetikan. Pemasar juga perlu mengkomunikasikan ulang terkait jaminan kualitas produk sehingga konsumen benar-benar yakin terkait kualitas green cosmetics yang ditawarkan sehingga biaya yang harus dikeluarkan untuk membeli green cosmetics tidak dirasa mahal.

\section{Pengaruh Purchase Preferences terhadap Purchase Intention}

$\mathrm{H} 2$ dapat dibuktikan dengan hasil adanya pengaruh signifikan antara variabel purchase preferences terhadap purchase intention. Artinya, terdapat hubungan positif antara kedua variabel yang diuji. Hasil penelitian ini sesuai dengan hasil penelitian (Khan \& Salim, 2020).

Wanita bekerja dikenal sebagai pribadi yang teliti dan tidak gegabah dalam mengambil keputusan (Lusina, 2016). Hal ini menyebabkan wanita bekerja sangat jeli dalam menentukan pilihan terkait produk kosmetik yang digunakan. Mayoritas responden penelitian merupakan pengguna green product. Jenis green product yang dikonsumsi oleh para wanita bekerja yaitu skincare, peralatan makan yang eco-friendly, dan tas belanja ramah lingkungan. Merek green product yang banyak digunakan yaitu Nature Republic, Innisfree, Oriflame, The Body Shop, dan Tupperware. Akan tetapi, persentase wanita bekerja yang menggunakan green cosmetics masih kalah dibandingkan persentase wanita bekerja yang menggunakan non-green cosmetics. Hal ini menjadi peluang bagi pemasar untuk menawarkan green cosmetics pada pengguna green product. Terlebih karena pengguna green product 
Catresia Martha Bella \& Yessy Artanti. Sebuah Studi pada Wanita Bekerja: Pengaruh Motivational Factors, Purchase Preferences, dan Tendency towards Health Consciousness terhadap Purchase Intention Green Cosmetics.

sudah memahami manfaat yang diperoleh untuk diri dan lingkungannya ketika menggunakan green product.

Informasi tambahan didapatkan berkaitan dengan di mana dan bagaimana responden membeli serta mencari informasi mengenai green product. Produk-produk tersebut mereka beli secara online maupun offline. Sebelum melakukan pembelian, kebanyakan responden melakukan pencarian informasi produk melalui media sosial. Selain itu mereka juga melakukan pencarian informasi produk melalui internet dengan membaca review product ataupun dengan mendatangi langsung gerai offline green product. Pengetahuan terkait green product lainnya mereka dapat juga dari media sosial. Ada juga yang menyebutkan bahwa mereka mengetahui green product dari teman, iklan, keluarga, dan rekan kerja.

\section{Pengaruh Tendency towards Health Consciousness terhadap Purchase Intention}

Wanita bekerja sering kali merasa kelelahan akibat padatnya aktivitas. Kelelahan yang berkepanjangan sangat rentan terhadap penyakit. Maka dari itu, penting bagi seorang wanita bekerja untuk menjaga kesehatan (White, 2021). Kesadaran kesehatan menuntun para wanita bekerja untuk mencari atau bahkan menggunakan produk-produk yang ramah lingkungan. Penelitian ini membuktikan variabel tendency towards health consciousness memiliki pengaruh yang signifikan terhadap purchase intention. Hasil ini sejalan dengan hasil penelitian Khan \& Salim (2020) dan Kim \& Chung (2011) yang menyatakan bahwa kesadaran kesehatan berpengaruh signifikan positif terhadap purchase intention.

Wanita bekerja yang menggunakan green product dimungkinkan memiliki ketertarikan juga untuk menggunakan green cosmetics sebagai produk perawatan tubuh dan wajahnya. Sikap positif wanita bekerja terhadap green cosmetics ini salah satunya disebabkan oleh kepercayaan bahwa green cosmetics aman bagi kesehatan. Sehingga, para wanita bekerja dapat menggunakan green cosmetics tanpa takut merusak kesehatan kulit. Tingginya kesadaran wanita bekerja terhadap kesehatan ini memberikan peluang bagi para pelaku bisnis untuk mengembangkan bisnisnya kearah produk ramah lingkungan atau merubah image konvensionalnya menjadi green beauty. Selain mendorong wanita bekerja menggunakan green product, kesadaran kesehatan juga mendorong wanita bekerja untuk menjaga lingkungan sekitar. Mereka menggunakan produk ramah lingkungan, mengurangi penggunaan plastik di kehidupan sehari-hari, dan mengedukasi atau memberikan informasi kesehatan ke teman atau orang-orang terdekat.

\section{KESIMPULAN}

Berdasarkan pembahasan dan hasil penelitian yang telah dipaparkan, dapat disimpulkan bahwa motivational factors tidak berpengaruh signifikan terhadap purchase intention green cosmetics pada wanita bekerja. Tidak adanya pengaruh ini dikarenakan wanita bekerja tidak termotivasi melakukan pembelian green cosmetics yang terkenal mahal. Sedangkan purchase preferences dan tendency towards health consciousness berpengaruh signifikan terhadap purchase intention green cosmetics pada wanita bekerja. Purchase preferences memiliki pengaruh positif dikarenakan adanya selera wanita bekerja menggunakan produk-produk ramah lingkungan. Hal ini yang kemudian memengaruhi wanita bekerja mencoba ataupun menggunakan green cosmetics yang aman untuk kesehatan. Tendency towards health consciousness dipengaruhi oleh tingginya tingkat kesadaran kesehatan wanita bekerja. Penelitian ini berfokus pada kelompok wanita bekerja. Penelitian selanjutnya dapat melibatkan variabel demografis, pengeluaran untuk membeli green product, dan variabel gaya hidup. Penelitian selanjutnya juga dapat menggunakan in-depth interview dan focus group discussion untuk mengetahui lebih detail terkait penggunaan green product. Green product juga erat kaitannya dengan high-involvement product. Hal ini menjadi menarik untuk melibatkannya pada penelitian selanjutnya.

\section{DAFTAR PUSTAKA}

Anojan, V., \& Subaskaran, T. (2015). Consumer's Preference and Consumer's Buying Behavior on 
Soft Drinks: A Case Study in Northern Province of Sri Lanka. Global Journal of Management and Business Research, 15(2), 11-33.

Arum, N. (2019). 8 Rekomendasi Brand Kecantikan yang Ramah Lingkungan. Ada Kosmetik yang Kemasannya dari Bambu Lo! Retrieved April 29, 2021, from hipwee website: https://www.hipwee.com/style/kosmetik-ramah-lingkungan/

Banks, S. (2014). The Relationships Between Preference and Purchase of Brands. Journal of Marketing, 15(2), 145-157. https://doi.org/10.2307/1247660

Becker, M. H., Maiman, L. A., Kirscht, J. P., Haefner, D. P., \& Drachman, R. H. (1977). The Health Belief Model and Prediction of Dietary Compliance: A Field Experiment. Journal of Health and Social Behavior, 18(4), 348-366. https://doi.org/10.2307/2955344

Bhatnagar, A., \& Ghose, S. (2004). Segmenting consumers based on the benefits and risks of Internet shopping. Journal of Business Research, 57(12 spec.iss.), 1352-1360. https://doi.org/10.1016/S0148-2963(03)00067-5

Blackwell, R. D., Miniard, P. W., \& Engel, J. F. (2012). Consumer Behavior. Singapore: Cengage Learning Asia Pte Ltd.

Carey, L., \& Cervellon, M.-C. (2011). Consumers' perceptions of "green": Why and how consumers use eco-fashion and green beauty products. Critical Studies in Fashion \& Beauty, 2(1\&2), 117138. https://doi.org/10.1386/csfb.2.1-2.117

Carlson, J., \& O'Cass, A. (2010). Exploring the relationships between e-service quality, satisfaction, attitudes and behaviours in content-driven e-service web sites. Journal of Services Marketing, 24(2), 112-127. https://doi.org/10.1108/08876041011031091

Chin, J., Jiang, B. C., Mufidah, I., Persada, S. F., \& Noer, B. A. (2018). The investigation of consumers' behavior intention in using green skincare products: A pro- environmental behavior model approach. Sustainability (Switzerland), 10(11). https://doi.org/10.3390/su10113922

Cleanomic. (2020). 9 Green Beauty Brands Terfavorit. Retrieved April 29, 2021, from Cleanomic.co.id website: https://www.cleanomic.co.id/post/9-green-beauty-brands-terfavorit

Cox, J. C., \& Grether, D. M. (1993). The Preference Reversal Phenomenon: Response Mode, Markets and Incentives. Economic Theory, 7(3), 381-405. https://doi.org/10.1007/BF01213657

Ghazali, E., Soon, P. C., Mutum, D. S., \& Nguyen, B. (2017). Health and cosmetics: Investigating consumers' values for buying organic personal care products. Journal of Retailing and Consumer Services, 39, 154-163. https://doi.org/10.1016/j.jretconser.2017.08.002

Gould, S. J. (1988). Health and Health Care: A Differential Perspective. The Journal of Consumer Affairs, 22(1), 96-118. https://doi.org/10.1111/j.1745-6606.1988.tb00215.x

Grace. (2020). 5 Merek Kosmetik Natural yang Usung Konsep Ramah Lingkungan. Retrieved April 29, 2021, from popmama.com website: https://www.popmama.com/life/fashion-andbeauty/grace/kosmetik-ramah-lingkungan/5

Hsu, C. L., Chang, C. Y., \& Yansritakul, C. (2017). Exploring purchase intention of green skincare products using the theory of planned behavior: Testing the moderating effects of country of origin and price sensitivity. Journal of Retailing and Consumer Services, 34(September 2016), 145-152. https://doi.org/10.1016/j.jretconser.2016.10.006 
Catresia Martha Bella \& Yessy Artanti. Sebuah Studi pada Wanita Bekerja: Pengaruh Motivational Factors, Purchase Preferences, dan Tendency towards Health Consciousness terhadap Purchase Intention Green Cosmetics.

Johri, L., \& Sahasakmontri, K. (1999). Green Marketing of Cosmetics \& Toiletries in Thailand.pdf. 15(3), 265-281.

Jones, P. (2021). Top 10 characteristics of successful and creative women. Retrieved June 16, 2021, from thejobnetwork.com website: https://www.thejobnetwork.com/10-traits-of-successfulwomen/

Katadata. (2019). Jumlah Penduduk Indonesia 2019 Mencapai 267 Juta Jiwa. Retrieved April 23, 2021, from Katadata.co.id website: https://databoks.katadata.co.id/datapublish/2019/01/04/jumlah-penduduk-indonesia-2019mencapai-267-juta-jiwa

Kemenperin. (2018, March 20). Kemenperin: Industri Kosmetik Nasional Tumbuh 20\%. Retrieved December 2, 2020, from Kemenperin.go.id website: https://kemenperin.go.id/artikel/18957/Industri-Kosmetik-Nasional-Tumbuh-2018

Khan, S., \& Salim, A. (2020). Saudi females' buying behavior of green cosmetics: A pertinent motivational aspect. Journal of Marketing Communications, 00(00), 1-13. https://doi.org/10.1080/13527266.2020.1720268

Khumaira, K., \& Restu, R. Y. S. (2018). Hubungan Antara Harga Diri, Citra Tubuh, dan Dukungan Teman Sebaya terhadap Perilaku Konsumtif pada Mahasiswa Konsumen Klinik Perawatan Kecantikan. Journal of Chemical Information and Modeling, 53(9), 1689-1699.

Kotler, P., \& Keller, K. L. (2016). Marketing Management (15th ed.). Harlow: Pearson Education Limited 2016.

Kotler, P., \& Amstrong, G. (2011). Principles of Marketing (Vol. 14th ). In Principles of Marketing $14 \mid$ Philip Kotler Northwestern University Gary Armstrong University of North Carolina ( $\mathrm{p}$. 147). Pearson Prentice Hall.

Lee, H. (2016). Individual and Situational Determinants of U.S. Consumers' Buying Behavior of Organic Foods. Journal of International Food and Agribusiness Marketing, 28(2), 117-131. https://doi.org/10.1080/08974438.2015.1035471

Liobikienè, G., \& Bernatonienè, J. (2017). Why determinants of green purchase cannot be treated equally? The case of green cosmetics: Literature review. Journal of Cleaner Production, 162, 109-120. https://doi.org/10.1016/j.jclepro.2017.05.204

Liobikiene, G., Mandravickaite, J., \& Bernatoniene, J. (2016). Theory of planned behavior approach to understand the green purchasing behavior in the EU: A cross-cultural study. Ecological Economics, 125, 38-46. https://doi.org/10.1016/j.ecolecon.2016.02.008

Lombardo, J. (2020). Consumer Preferences \& Choice in Economics. Retrieved April 30, 2021, from https://study.com/academy/lesson/consumer-preferences-choice-in-economics.html

Lusina. (2016). Ini Bukti Nyata Wanita Bekerja Lebih Baik ketimbang Pria. Retrieved June 18, 2021, from Kompas.com website: https://lifestyle.kompas.com/read/2016/05/10/110600920/Ini.Bukti.Nyata.Wanita.Bekerja.Lebi h.Baik.ketimbang.Pria

Magnusson, M. K., Arvola, A., Hursti, U. K. K., Åberg, L., \& Sjödén, P. O. (2003). Choice of organic foods is related to perceived consequences for human health and to environmentally friendly behaviour. Appetite, 40(2), 109-117. https://doi.org/10.1016/S0195-6663(03)00002-3 
Martha, M., \& Febriyantoro, M. (2019). Analisis Faktor-Faktor Yang Mempengaruhi Perilaku Pembelian Produk Kosmetik Ramah Lingkungan. Jurnal Ecodemica: Jurnal Ekonomi, Manajemen, Dan Bisnis, 3(2), 218-227. https://doi.org/10.31311/jeco.v3i2.6117

Melliana, A. (2006). Menjelajah Tubuh Perempuan dan Mitos Kecantikan. Yogyakarta: LKiS Yogyakarta.

Molinillo, S., Vidal-Branco, M., \& Japutra, A. (2020). Understanding the drivers of organic foods purchasing of millennials: Evidence from Brazil and Spain. Journal of Retailing and Consumer Services, 52(January 2019), 101926. https://doi.org/10.1016/j.jretconser.2019.101926

Newman, A., \& Japarianto, D. E. (2014). Pengaruh Motivation Terhadap Purchase Intention Dengan Perception Sebagai Variabel Intervening Di Toko Obat Tradisional Ban Seng Tong Surabaya. Jurnal Manajemen Pemasaran Petra, 2(1), 1-9.

Papalia, D. E., Sterns, H. L., Feldman, R. D., \& Camp, C. J. (2007). Adult development and aging (3rd ed.). Boston: McGraw-Hill.

Puh, B. (2016). Consumers' Purchase Intentions Towards Natural Cosmetics. Ekonomski Vjesnik / Econviews: Review of Contemporary Business, Entrepreneurship and Economic Issues, 29(1), 53-64.

Rukmawati, D. R., \& Dzulkarnain, I. (2015). Konstruksi Kecantikan Di Kalangan Wanita Karier (Di Kecamatan Lamongan, Kabupaten Lamongan). Dimensi- Journal of Sociology, 8(1). Retrieved from http://journal.trunojoyo.ac.id/dimensi/article/view/3722

Sadiq, M., Adil, M., \& Paul, J. (2020). An innovation resistance theory perspective on purchase of eco-friendly cosmetics. Journal of Retailing and Consumer Services, xxx(xxxx), xxx. https://doi.org/10.1016/j.jretconser.2020.102369

Schiffman, L. ., \& Kanuk, L. L. (2007). Consumer Behavior (9th edition). New Jersey: Prentice Hall Private Limited Publishing.

Setiadi, N. (2013). Perilaku Konsumen : Perspektif Kontemporer Pada Motif, Tujuan, dan Keinginan Konsumen (Vol. V). Jakarta: Kencanca Prenada Media Group.

Sindo. (2012, March 12). Kosmetik "Hijau" Bukan Mimpi : Okezone Lifestyle. Retrieved December 2, 2020, from lifestyle.okezone.com website: https://lifestyle.okezone.com/read/2012/03/12/28/591564/kosmetik-hijau-bukan-mimpi

Sugiyono. (2017). Metode Penelitian Pendidikan (Pendekatan Kuantitatif, Kualitatif dan R\&D). CV. Alfabeta.

Sundarambal, K., \& Edhayavarman. (2017). a Study on Consumer Preference on Cosmetics Among College Girls With. Paripex- Indian Journal of Research, 6(3), 645-648.

Suri, R., \& Monroe, K. B. (2003). The Effects of Time Constraints on Consumers' Judgments of Prices and Products. Journal of Consumer Research, 30(1), 92-104. https://doi.org/10.1086/374696

Tandon, A., Dhir, A., Kaur, P., Kushwah, S., \& Salo, J. (2020). Behavioral reasoning perspectives on organic food purchase. Appetite, 154, 104786. https://doi.org/10.1016/j.appet.2020.104786

Trisnawati, F. A., Yulianti, C. H., \& Ebtavanny, T. G. (2017). Identifikasi Kandungan Merkuri pada Beberapa Krim Pemutih yang Beredar di Pasaran (Studi dilakukan di Pasar DTC Wonokromo 
Catresia Martha Bella \& Yessy Artanti. Sebuah Studi pada Wanita Bekerja: Pengaruh Motivational Factors, Purchase Preferences, dan Tendency towards Health Consciousness terhadap Purchase Intention Green Cosmetics.

Surabaya). Journal of Pharmacy and Science, 2(2). Retrieved from http://www.ejournal.akfarsurabaya.ac.id/index.php/jps/article/view/79

Weddy, I., \& Febrya, V. (2016). Penggunaan "Green Cosmetic" dalam Mewujudkan Perilaku Kesadaran Lingkungan. Ilmu Lingkungan, 10(2), 199-203.

Wetzstein, M. (2020). Consumer Preferences (2nd ed., Vol. 6). Routledge. https://doi.org/10.4324/9780203098356-7

White, R. (2021). Wanita Karir: Tips Pengembangan Diri 2021. Retrieved June 18, 2021, from raywhite.co.id website: https://www.raywhite.co.id/news/152944wanita-karir-adalah-wanitayang-luar-biasa

Widiyani, R. (2018, November 26). Ini Nih Tips dari Bu Polwan Soal Memilih Kosmetik Aman. Retrieved January 14, 2021, from health.detik.com website: https://health.detik.com/beritadetikhealth/d-4317107/ini-nih-tips-dari-bu-polwan-soal-memilih-kosmetik-aman

Wu, J. J., Chen, Y. H., \& Chung, Y. S. (2010). Trust factors influencing virtual community members: A study of transaction communities. Journal of Business Research, 63(9-10), 1025-1032. https://doi.org/10.1016/j.jbusres.2009.03.022

Xie, B., Wang, L., Yang, H., Wang, Y., \& Zhang, M. (2015). Consumer perceptions and attitudes of organic food products in Eastern China. British Food Journal, 117(3), 1105-1121. https://doi.org/10.1108/BFJ-09-2013-0255

Yadav, R. (2016). Altruistic or egoistic: Which value promotes organic food consumption among young consumers? A study in the context of a developing nation. Journal of Retailing and Consumer Services, 33, 92-97. https://doi.org/10.1016/j.jretconser.2016.08.008

Yohana. (2020, March 22). Pertarungan Industri Kosmetik dengan Budaya Indonesia - Yonulis. Retrieved December 2, 2020, from yonulis.com website: https://yonulis.com/2020/03/22/pertarungan-industri-kosmetik-dengan-budaya-indonesia/

Zeithaml, V. A. (1988). Consumer Perceptions of Price, Quality, and Value: A Means-End Model and Synthesis of Evidence. Journal of Marketing, 52(3), 2-22. https://doi.org/10.1177/002224298805200302 